\title{
Synthesis and biological evaluation of novel pyridazine analogues (3-aldehyde-1-phenylpyridazine derivatives)
}

\author{
E. M. ODIN * and M. PATIENCE \\ Department of Chemistry, Kogi State Univerity, Anyigba, Nigeria. \\ * Corresponding author, E-mail: odinem2005@yahoo.com, GSM: 08057866179
}

\begin{abstract}
Five new pyridazine compounds were synthesized. The usefulness of IR, ${ }^{1} \mathrm{HNMR}$ and ${ }^{13} \mathrm{CNMR}$ spectroscopy for the structural analysis of the new compounds is well established. The differences in molecular structure between one absorbing compound and another affected a shift in absorption wavelength $(\lambda \max )$. The structure-activity relationship among the pyridazine derivatives was measured against some pathogens. Compound $3 \mathrm{e}$ was found to be a more active drug than the standard antibiotic, streptomycin $\mathrm{SO}_{4}$. (c) 2010 International Formulae Group. All rights reserved.
\end{abstract}

Keywords: Biological evaluation, novel, pyridazine derivatives, antimicrobial agents.

\section{INTRODUCTION}

Pyradazine has no household use. It is mainly used in research and pharmaceuticals as building blocks for more complex compounds (Bourguignon et al., 2006). Interest in pyridazine derivatives has remained unabated due to their biological activities as antiplatelet agents (Coetho et al., 2004), antimicrobial agents (Deeb et al., 2004), anti-inflamatory agent (Webster, 2002) and anti-depresant (Nemmeroff, 1988). Attempts have been made by Chemists to synthesize and characterize compounds containing pyridazine functionality in order to explore the usefulness of this heterocyclic template. Generally, the presence of a pyridazine structure in a bioactive molecule confers good bioavailability, especially with the central nervous system (CNS). The purpose of this study was to synthesize, evaluate the biological importance of 3aldehyde-1-phenylpyridazine derivatives (3ae) as presented in scheme 1 and examine structure-activity relationship.

\section{MATERIALS AND METHODS}

All chemicals were obtained from Chemistry Department, Kogi State University and were used without further purification. The melting points (m.p) were determined on a SMP3 melting point apparatus and were reported in ${ }^{\circ} \mathrm{C}$ uncorrected. Column Chromatography was performed on Scharlan Silica gel 60 (70-230 mesh). Elemental analysis was performed using a Perkin-Elmer 2400 II CHN Analyser (Paperno et al, 1997).

The infrared (IR) spectra were recorded in $\mathrm{CM}^{-1}$ on a Bulk Scientific 500 spectrophotometer. The ${ }^{1} \mathrm{H}$ and ${ }^{13} \mathrm{C}-\mathrm{NMR}$ spectra were recorded on a varian Germini 2000 spectrophotometer operating 200 and 50 $\mathrm{MH}_{\mathrm{z}}$ respectively. Chemical shifts were recorded as 6 values in PPM referenced to the solvent. HPLC separations were performed on a Bulk Scientific 500 apparatus using a reverse phase Lichrospher $100 \mathrm{RP}-18$ (5 M) column, at room temperature (eluent: methanol/water 8:2, v/v). Antimicrobia activity tests were carried out at the microbiology Laboratory Faculty of Natural Sciences Kogi State University. The 
compounds (3a-e) were prepared according to the method of Dilek et al. (2006) and Alberto et al. (2003).

\section{3-aldehyde-1-phenylpyridazine (3a)}

This compound was prepared by refluxing an equimolar mixture of furfural $(1.7 \mathrm{ml}, 0.02 \mathrm{~mol})$ and phenylhydrazine 92.89 $\mathrm{g}, 0.02 \mathrm{~mol})$ in toluene $(20 \mathrm{ml})$ for four hours. The solvent (toluene) was removed by evaporation and the oily residue was treated with diethyl ether overnight. The crude product formed was crystallized from acetic acid to give $(58 \%)$ of $3 \mathrm{a}$. m.p: $356{ }^{\circ} \mathrm{C}-358{ }^{\circ} \mathrm{C}$. IR:1714 (C=O), 3475 (NH-Ar), $1670(\mathrm{C}-\mathrm{N})$, 886 (C-H-Ar), 1391 (C-H bending), 1600 (C=C-Ar), $2675.60 \quad$ (C-H stretchers). ${ }^{1} \mathrm{H}$ NMR (200 $\left.\mathrm{MH}_{\mathrm{z}}\right)$ : 7.798 (s.Ar-H), 10.724 (s.NH), ${ }^{13}$ CNMR (50 $\left.\mathrm{MH}_{\mathrm{z}}\right): 1842(\mathrm{~s}, \mathrm{C}=\mathrm{O})$, 180.74 (s. C3), 169.82 (s.C4), 186.32 (s.C5) 125.34 (s.C6). 148.72-136.40 (m. Ar.C)

\section{3-aldehyde-1,5,6,-triphenylpyridazine (3b)}

The general procedure as in $3 \mathrm{a}$ was applied by reacting compound $1 \mathrm{~b}$ with $2 \mathrm{~b}$. This was refluxed for $4 \mathrm{hrs}$, resulting in $(55 \%)$ of 3b. mp: $403-406{ }^{\circ} \mathrm{C}$. IR: 3452 (NH-Ar), $1718(\mathrm{C}=\mathrm{O}), 882$ (C-H-Ar), $1684(\mathrm{C}-\mathrm{N}), 1606$ $(\mathrm{C}=\mathrm{C}-\mathrm{Ar}){ }^{1} \mathrm{H}$ NMR $\left(200 \mathrm{MH}_{\mathrm{z}}\right): 7.890$ (s.ArH), 10.926 (s.N-H), ${ }^{13} \mathrm{CNMR} \quad\left(50 \quad \mathrm{MH}_{\mathrm{z}}\right)$ : 186.48 (m.C=O), 181.62 (s.C3) 169.70 (s.C4), 190.40 (s.C5), 140.28 (C6) 152.68-147.10 (m.Ar.C).

\section{3-aldehyde-1-orthoanizidine-5-hydroxy- pyridazine (3c)}

Compound $3 \mathrm{c}$ was prepared by reacting compound $1 \mathrm{c}$ with $2 \mathrm{c}$. Refluxing was for $4 \mathrm{hrs}$. This yielded $(60 \%)$ of $3 \mathrm{c} \mathrm{mp:} 368$ $371{ }^{\circ} \mathrm{C}$. IR: $1715(\mathrm{C}=\mathrm{O}), 3478$ (NH-Ar) 1672 (C-N), 886 (C-H-Ar), $3300(\mathrm{OH}), 3450$ $\left(\mathrm{NH}_{2}\right){ }^{1} \mathrm{HNMR}\left(200 \mathrm{MH}_{\mathrm{z}}\right): \quad 4.79\left(\mathrm{~s}, \mathrm{OCH}_{3}\right)$, 5.890(s.NH $\left.\mathrm{NH}_{2}\right), 10.340$ (s.N-H), 7.635 (s.Ar-H) ${ }^{13}$ CNMR (50 $\mathrm{MH}_{\mathrm{z}}$ ): 183.80 (s.C=O), 181.71 $\left(\mathrm{sC}_{3}\right) 167.71$ (s.C4), 184.38 (s.C5), 123.38 (s.C6), 147.42-138.39 (m.Ar.C).

\section{3-aldehyde-1-aniline-5,6-dihydroxy pyridazine (3d)}

Compound $3 \mathrm{~d}$ was prepared according to the general procedure by the reaction of $1 \mathrm{~d}$ and $2 \mathrm{~d}$ with a reflux time of 4 hrs. This gave a yield of 65\%. mp: 370-373 ${ }^{\circ} \mathrm{C}$. IR: $1720(\mathrm{C}=\mathrm{O}), 3478$ (NH-Ar), 1680 (C-
N), 888 (C-H-Ar), $3402\left(\mathrm{NH}_{2}\right), 3350(\mathrm{OH})$. ${ }^{1} \mathrm{HNMR}\left(200 \mathrm{MH}_{\mathrm{z}}\right)$ : $5.920\left(\mathrm{~s} . \mathrm{NH}_{2}\right), 10.410$ (s.N-H), 7.813 (s.Ar-H). ${ }^{13}$ CNMR (50 $\left.\mathrm{MH}_{\mathrm{z}}\right)$. 182.81 (s.C=O), 182.92 (s.C $\left.{ }_{3}\right) 167.83\left(\right.$ s.C $\left._{4}\right)$, 190.48 (s.C5), 127.39 (s.C6) 149.68-139.47 (m. Ar. C).

\section{3-aldehyde-5-hydroxy-1-otho-toluidine-6- prenylpyradazine (3e)}

Compound $3 \mathrm{e}$ was prepared according to the general procedure by the reaction of $1 \mathrm{e}$ and $2 \mathrm{e}$ with a reflux time of $4 \mathrm{hr}$. This gave a yield of $67 \%$. mp: $382-385{ }^{\circ} \mathrm{C}$. IR: $1723(\mathrm{C}=\mathrm{O}), 3476$ (NH-Ar), $1683(\mathrm{C}-\mathrm{N})$ 884 (C-H-Ar), $3459\left(\mathrm{NH}_{2}\right), 3353(\mathrm{OH}), 1381$ $(-\mathrm{C}=\mathrm{C}) .{ }^{1} \mathrm{HNMR}\left(200 \mathrm{MH}_{\mathrm{z}}\right): 6.830\left(\mathrm{~s} . \mathrm{NH}_{2}\right)$, 9.894 (s.N-H), 7.481 (s.Ar.H), $2.42\left(\mathrm{~s} . C H_{3}\right)$ ${ }^{13} \mathrm{CNMR}\left(50 \mathrm{MH}_{\mathrm{z}}\right)$ : $182.70(\mathrm{~s} . \mathrm{C}=\mathrm{O}), 182.96$ (s.C. $), 167.90$ (s.C. $), 190.50$ (s.C5), 124.91 (s.C6) 148.71-146.16 (m.Ar.C).

\section{Antimicrobial activity test}

The antimicrobial screening method employed was the Agar-Dilution streak methods of Akpulu et al. (1994) and Peter et al. (2002). The antimicrobial activity was measured by determining the concentration of agent needed to inhibit the growth of test microorganisms.

Clinical isolates, including Pseudomonas species, Escherichia species, Citrobacter species, Salmonella species, Shigella species, M. Spegmatis species, Klebsiella species and $S$. aureus species, were obtained from the National Institute for Pharmaceutical Research and Development (NIPRD).

The Agar and Pyridazine sample were poured into sterile dishes, allowed to set and inoculated with the organism by streaking and incubated at $37{ }^{\circ} \mathrm{C}$ for $24 \mathrm{hrs}$ in duplicate. Control plates which contained no Pyridazine sample to ensure viability and for comparison were similarly inoculated and incubated. After incubation, susceptibility and inhibition were measured by absence of growth.

\section{RESULTS}

The structures of compounds $3 \mathrm{a}-\mathrm{e}$ were confirmed by elemental analysis, IR, ${ }^{1} \mathrm{HNMR}$ and ${ }^{13}$ CNMR data obtained. The spectral analysis of the compounds (3a-e) confirmed the characteristic functional groups, the types 
of bonds present, protons and carbon atoms present.

From scheme 1, it is believed that the reaction starts with the interaction of the nitrogen atom bearing $R_{2}$ radical in phenylhydrazine and $\mathrm{C} 5$ of the furan-2aldehyde (Dilek et al., 2006). This suggests that the interaction of $\mathrm{C} 5$ and nitrogen constitutes the first stage of the reaction.

From Table 1, it is evident that compound $3 \mathrm{a}$ absorbed at $360 \mathrm{~nm}$, while pyridazine molecule absorbed at $246 \mathrm{~nm}$. This bathochromic shift may be assigned to substituent groups attached to the pyridazine ring in compound $3 \mathrm{a}$, that is the phenyl group at postion-1 and the carbonyl group at position 3.

Compound, $3 \mathrm{~b}-\mathrm{e}$ absorbed in the range 367-390 nm. This powerful bathochromic shift is probably due to high molecular weight of the compounds and the presence of a prenyl group in compound $3 \mathrm{e}$ which increased the unsaturation of the compound.

The results of the biological tests are as presented in Table 2 .

Table 1: Some physical characteristics of synthesized compounds.

\begin{tabular}{lcc}
\hline Compound & $\begin{array}{c}\lambda \max \\
(\mathrm{nm})\end{array}$ & Melting point $\left({ }^{\circ} \mathrm{C}\right)$ \\
\hline Pyridazine & 246 & -8 \\
$3 \mathrm{a}$ & 360 & $356-358$ \\
$3 \mathrm{~b}$ & 381 & $403-406$ \\
$3 \mathrm{c}$ & 367 & $368-371$ \\
$3 \mathrm{~d}$ & 372 & $370-373$ \\
$3 \mathrm{e}$ & 390 & $382-385$ \\
\hline
\end{tabular}<smiles>[R][X]C(=O)c1cc([R])c([R])o1</smiles><smiles>[R]CCCCC[R]</smiles>

$\begin{array}{lllll} & \mathbf{1} & \mathbf{2} & \mathbf{3} & \\ 1 & \mathrm{R}_{1} & \mathrm{R}_{2} & \mathrm{R}_{1} & \mathrm{R}_{2} \\ \mathrm{a} & \mathrm{H} & \mathrm{Ph} & \mathrm{H} & \mathrm{ph} \\ \mathrm{b} & \mathrm{Ph} & \mathrm{Ph} & \mathrm{Ph} & \mathrm{Ph} \\ \mathrm{c} & \mathrm{OH}, \mathrm{H} & \text { o-anizidin } & \mathrm{O} \mathrm{H} & \text { o-anizidin } \\ \mathrm{d} & \text { OHOH } & \text { aniline } & \mathrm{OH} & \text { aniline } \\ \mathrm{e} & \text { OH, Prenyl group } & \text { o-toluidine } & \mathrm{OH}, \text { Prenyl } & \text { o-toluidine }\end{array}$

Scheme 1: Synthesis of pyridazine-3-al derivatives. 
Table 2: Structure and antibacterial activity (MIC) of pyridazine derivatives against some pathogens.

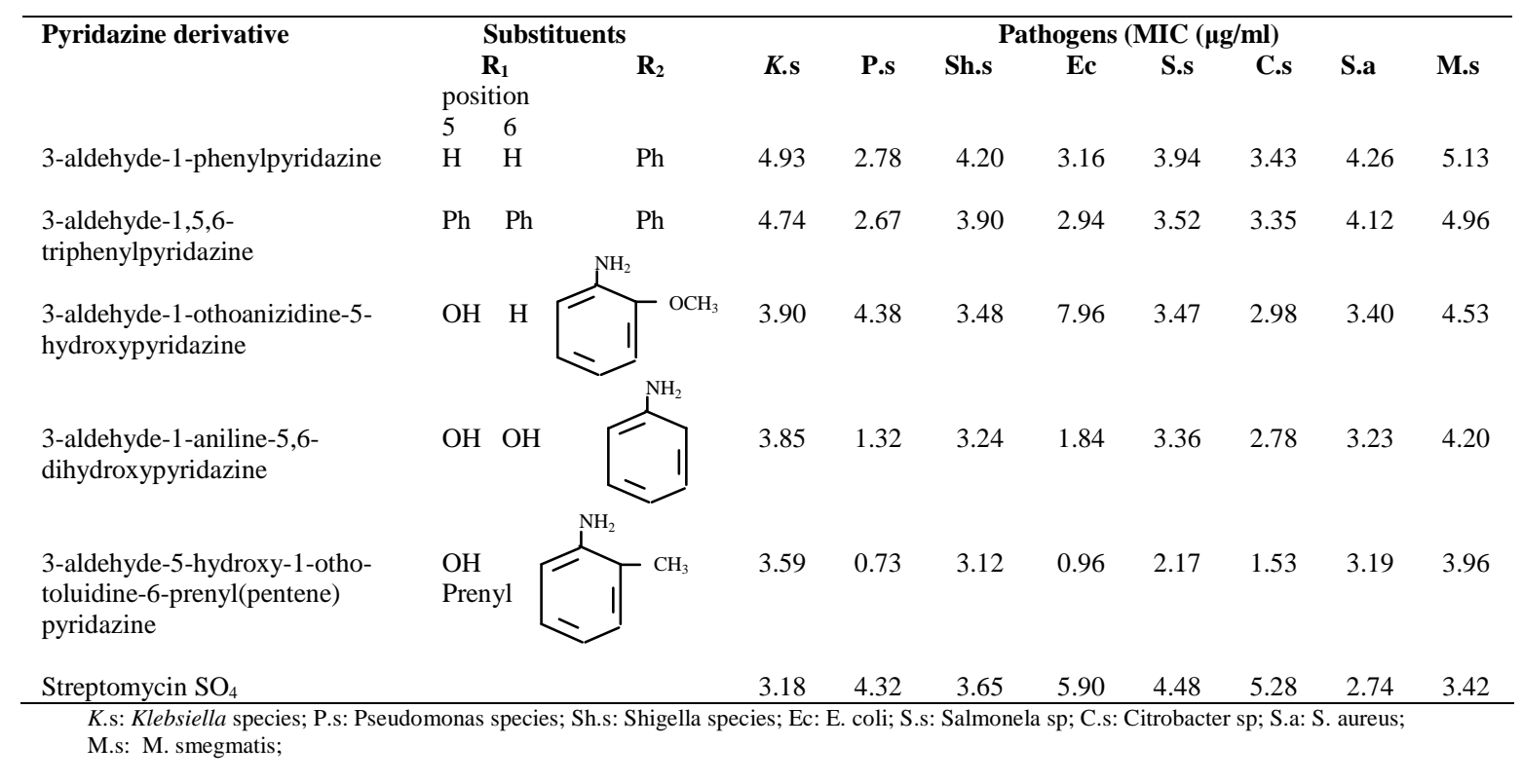<smiles>Nc1ccc(N2CC(O)=CC(=O)N2)cc1</smiles>

3c<smiles>Nc1ccc(N2NC(C=O)=CC(O)=C2O)cc1</smiles>

3d<smiles>CC=CC1=C(O)C=C(C=O)N(c2ccc(N)c(C)c2)N1</smiles>

$3 \mathbf{e}$

\section{DISCUSSION}

Table 1 supports the fact that relatively minor differences in molecular structure between one absorbing substance and another may bring about a shift in absorption wavelength, $\lambda \max$. As one and more unsaturated linkages occur in the molecule, so $\Delta \max$ is displaced towards longer wavelength. This shows that structural factors determine whether or not a molecule will absorb in the visible. They also decide where such absorption will occur (Abrahart, 1968). The high melting point of the synthesized compounds (3a-e) is an indication of stability of the compounds.

The structure activity relationship among the pyridazine derivatives were measured against eight pathogens (Okwute and Mitscher, 1992). The activity of the 
pyridazine compounds against the eight bacterial strains are provided in table 2 . The activity of the compounds varies depending on structure. From table 2, all the compounds were active on the eight microorganisms. Compound $3 \mathrm{e}$ showed the greatest activity of $0.73 \mu \mathrm{g} / \mathrm{ml}$ against Pseudomonas species, $0.96 \mu \mathrm{g} / \mathrm{ml}$ against Escherichia coli, $1.53 \mu \mathrm{g} / \mathrm{ml}$ against Citrobacter species and $2.17 \mu \mathrm{g} / \mathrm{ml}$ against salmonella species. This table also revealed compounds $3 \mathrm{e}$ to be a more active drug on pseudomonas species, shigella species, Escherichia coli, Salmonella species and Citrobecter species than the standard antibiotic, streptomycin $\mathrm{SO}_{4}$.

Generally, all the compounds showed activity between $0.73 \mu \mathrm{g} / \mathrm{ml}$ against pseudomonas species and $5.13 \mu \mathrm{g} / \mathrm{ml}$ against M. spegmatis. Interestingly, compound $3 \mathrm{c}$ and $3 \mathrm{~d}$ also showed remarkable activity on all the organisms. Examination of all the compounds revealed some important structural requirements for the antibacterial activity.

The presence of prenyl, hydroxyl and amino groups probably accounts for the higher activity of compounds $3 \mathrm{c}, 3 \mathrm{~d}$ and $3 \mathrm{e}$ shown below.

The similarity on the activity of compounds $3 \mathrm{c}$ and $3 \mathrm{~d}$ on all the microorganisms could be attributed to the presence of $\mathrm{OH}$ group on the pyridazine ring of the compounds but the presence of two hydroxyl groups on compound $3 \mathrm{~d}$ might be responsible for its higher activity.

All the compounds possess $\mathrm{OH}$ group except compounds $3 \mathrm{a} \& 3 \mathrm{~b}$. This could be responsible for their lower activity than streptomysin $\mathrm{SO}_{4}$ against Klebsiella sp. Shigella sp, S. aereus and M. smegmatis.

The presence of prenyl group in compound $3 \mathrm{e}$ enhanced the activity. This tends to suggest that the mode of antibacterial action may be aided by the presence of prenyl and hydroxyl groups on the pyridazine ring and to some extent the presence of amino group on the aromatic ring. The compounds possessing these groups on both ring displayed appreciable antibacterial activity, while those which completely lack these groups exhibited decrease activity.

This suggests that the substitution partern in each of the rings is a strong contributory factor to the degree of activity of the pyridazine compounds. Hence compound $3 \mathrm{e}$ has a greater activity than $3 \mathrm{~d}$, which in turn is greater than compound $3 \mathrm{c}$.

The $\mathrm{OH}$ group increases the lipophilic character of the pyridazine compounds that possess it. The group increases the ability of the compounds to permeat the cell-wall of the microorganism. The prenyl group enhances this permeation. Instead of the compound being traped in the bacterial that have high cell-wall lipid content, they are able to permeate the organism (compound 3e) (Okwute and Mitscher, 1992)

The exact role of the amino group is not understood but its importance to antimicrobial activity of some flavonoids has been reported (Odin et al., 2003)

\section{The mode of action}

The mechanism of action (Giovannoni et al., 2007) of the new pyridazine compounds consist of the following categories: Inhibition of cell wall synthesis, damage to cell membrane function, inhibition of nucleic acid synthesis or function and inhibition of protein synthesis. In gram-positive bacteria, the cell wall consist largely of a thick layer of peptidoglycan, which gives the cell rigidity and maintain a high internal osmotic pressure. In gram-negative bacteria, this layer is thinner and the internal osmotic pressure is correspondingly lower. The action of the pyridazine compounds is to block peptidoglycan synthesis, which severely weakens the cell wall. The compounds also interfere with protein synthesis by inhibiting the binding of aminoacyl tRNA to the recognition site and prevents peptide bonds from forming.

\section{Conclusion}

The high melting points indicate the stability of the synthesized compounds. The spectral data were used in the elucidation of the structures of the compounds. Structural factors affected absorbance $(\lambda \max )$ and the activity of the new pyridazines.

Compound $3 \mathrm{e}$ was found to be more active on Pseudomonas species, Shigella species, Escherichia coli, Salmonella species and Cintobacter species than the standard antibiotic, streptomycin $\mathrm{SO}_{4}$. The presence of 
prenyl group in the compound might be responsible for this activity.

\section{REFRENCES}

Abrahart EN. 1968. Dyes and their Intermediates. (vol. $1 ; 1^{\text {st }}$ edn). Pergamon Press Ltd: Great Britain; 127130.

Akpulu A, Hartman P. 1994. Natural Product as a source of potential cancer chemotherapeutic agents. J. Nat. Prod., 53: $23-41$.

Alberto C, Sotelo E, Ravina E. 2003. Sonogashira approaches in the synthesis of 5-substituted-6-phenyl-3(2H)pyridazinones. Tetrahedrom, 59(14): 2477-2484.

Coelho A, Sotelo E, Fraize N, Yanez M, Laguna R. 2004. Immunodulatory activity of thalidomide. Bioorg. Med. Chem. Lett., 14: 321.

Bourguignon JJ, Oumouch S, Schmitt M. 2006. Use of polyfunctionalized Pyridazines as reactive species for building chemical diversity. Currt. Org. Chem., 10(3): 277-295.

Deep AE, El-mariah F, Hoshyb M. 2004. Biological evaluation of substituted quinolines. Bioorg. Med. Chem. Lett., 14: 5013.

Dilek U, Emin S, Yunus A. 2006. A new method for the preparation of pyridazine systems. Turk J. Chem., 30: 691-701.
Giovannoni MP, Cesari N, Vergelli C, Gragianoa A, Biancalcani C, Biagini P, Dalpiaz V. 2007. 4-amino-5-substituted3-(2H)-pyridazinones as orally active anti-nocicepttive agents: Synthesis and studies on the mechanism of action $J$. Med. Chem., 50(16): 3945-3953.

Nemmeroff CB. 1988. Handbook of Clinical Psychoneuroendocriminology $\left(1^{\text {st }}\right.$ edn, vol. 2). Guilford Press: New York; 3849.

Odin EM, Okwute SK. 2003. Antiinflammatory and Analgesic properties of Newbouldia Laevis. Sav. J. Sci. Agric., 1: 20-32.

Okwut SK, Mitscher LA. 1992. Antibacterial Erythrinia pterocerpans; Structureactivity relationship analysis. Pharmacy World Journal, 9(2): 62-64.

Paperno TY, Pozdnyakov VP, Smirnova AA, Elazin LM. 1997. Physicochemical Laboratory Techniques ( $1^{\text {st }}$ edn). Mir Publishers Moscow; 100-156.

Peter B, Malanie L, Annemarie H, Herbert S, Joonho C, Huan-Ming C, Ramachandra S. 2002. Characterization of Imidazo [4,5-d] Pyridazine. Evidence for activity in the level of substrate and/or Enzyme. Antimicrob. Agents. Chem., 46(5): 12311239.

Webster El. 2002. Role of CRH in Peripheral Inflammation. J. Rheumatol., 29: 12521261. 